Turkish Online Journal of Qualitative Inquiry (TOJQI)

Volume 9, Issue 1, January 2018: 26-46

DOI: $10.17569 /$ tojqi.349800

Research Article

\title{
An Examination of Cyberloafing Behaviors in Classrooms from Students' Perspectives
}

\author{
Filiz Varol ${ }^{1}$, Esat Y1ldırım ${ }^{2}$
}

\begin{abstract}
Cyberloafing behaviors in education refer to students' behaviors of using technology (e.g., smartphones, laptops, and the Internet) for non-academic purposes during classes. Although there exist many studies on employees' cyberloafing tendency/behaviors, such studies are pretty limited in the field of education. Thus, the main goal of the current study is to investigate undergraduate students' cyberloafing behaviors in terms of instructor and student-related issues. In this qualitative study, the participants consisted of 228 undergraduate students in a state university. The participants were provided with open ended questions related to their possible cyberloafing behaviors. Content analysis was used for data analysis. The results were categorized under four themes: teacher related cyberloafing behaviors, suggestions for minimizing teacher-related cyberloafing behaviors, student related cyberloafing behaviors, suggestions for minimizing student-related cyberloafing behaviors. The results show instructors' communication styles and their teaching preferences lead students to cyberloafing behaviors. Furthermore, students' personal issues and lack of motivation resulted in misbehavior.
\end{abstract}

Keywords: Instructor-student, cyberloafing, teacher candidates, higher education.

\footnotetext{
${ }^{1}$ Assoc.Prof.Dr, Firat University, Faculty of Education, Department of Computer Education and Instructional Technology, fvarol@ firat.edu.tr, https://orcid.org/0000-0002-5060-7383

${ }^{2}$ Res.Asst., Kilis 7 Aralık University, Muallim Rifat Faculty of Education, Department of Basic Education, esatyldrmm@gmail.com, https://orcid.org/0000-0002-2292-4277

Geliş tarihi: 07.11.2017, Kabul tarihi: 31.01.2018
} 


\title{
Sınıfta Siberaylaklık Davranışlarının Öğrencilerin Bakış Açılarından İncelenmesi
}

\begin{abstract}
ÖZ
Bu çalışmanın amacı yükseköğrenimde öğrencilerin siberaylaklık yapma sebeplerini "öğrenci” ve "öğretmen (ders hocas1)" kapsamında incelemektir. Nitel araştırma yöntemlerinden faydalanılan bu araştırmanın çalışma grubunu, 2015-2016 eğitim-öğretim yılı güz döneminde bir devlet üniversitesinde okumakta olan 228 sınıf öğretmeni adayı oluşturmaktadır. Katılımcılara yöneltilen açık uçlu sorular sonucunda elde edilen veriler içerik analizi yöntemi ile değerlendirilmiştir. Bulgular dört ana başlık altında irdelenmiştir: öğretenden kaynaklı siberaylaklık davranışları, öğretenden kaynaklı siberaylaklık davranışlarını minimize etmek için öneriler, öğrenenden kaynaklı siberaylaklık davranışları ve öğrenenden kaynaklı siberaylaklık davranışlarını minimize etmek için öneriler. Elde edilen veriler doğrultusunda katılımcılar öğretim elemanının iletişim becerilerinden ve seçtikleri öğretim yöntem ve tekniklerinin kendilerini siberaylaklık davranışına yönlendirdiğini ifade etmiştir. Ayrıca kendi kişisel sorunlarının ve motivasyon düşüklüklerinin de benzer sonuç doğurduğunu söylemiştir.
\end{abstract}

Anahtar Sözcükler: Öğretmen-öğrenci, siberaylaklık, ögretmen adayl, yükseköğretim. 


\section{Introduction}

Information and communication technologies are being used widely in daily, professional and academic life, in home, work and school environments. Technologies such as desktop and notebook computers, tablets and mobile phones (smartphones) have become indispensable tools for individuals to perform working/learning tasks and satisfy their personal needs. On the other hand, with the introduction of the internet into professional life, it has become an issue for debate that employees may use the internet for personal purposes instead of performing workplace tasks.

In the literature, usage of company resources for personal reasons that are not directly related to the objectives of the company was generally defined as cyberslacking or cyberloafing (Blanchard and Henle, 2008; Bock and Ho, 2009; Lim, 2002; Philips \& Reddie, 2007; Whitty \& Carr, 2006). Cyberloafing may include activities such as reading personal e-mail, chatting online, shopping online, conducting banking operations, visiting adult websites or gambling/betting online (Blanchard \& Henle, 2008; Ugrin, Odom, \& Pearson, 2008; Vitak, Crouse, \& LaRose, 2011).

Rapid advancement of technology has also affected educational environments. Notebook computers, smartphones and wireless internet technologies are being used widely, especially in higher education environments. These technologies have benefits such as facilitating communication between the student and the instructor, providing access to course materials, offering course-related applications, and testing students. However, as in the case of workplaces, while students are expected to perform their learning activities when access to technology becomes easier in learning environments, they may also use these technologies for purposes other than course-related activities.

The first definition of cyberloafing in Turkey was provided by Kalaycı (2010) in the literature on the field of education. Accordingly, cyberloafing is students' tendency and/or behavior of using technology for non-academic purposes during classes. For example, cyberloafing may be defined as a student using the internet to read sports news, play games, check their e-mails or check their social media account while the instructor is teaching how a chart is drawn in Excel in a computer library. 
Notebook computers and smartphones have become indispensable tools in higher education due to their various advantages (Lauricella \& Kay, 2010; Weaver \& Nilson, 2005). However, studies have also revealed that usage of notebook computers / smartphones at school and especially the opportunity to use wireless internet at universities lead students to display behaviors that are not related to the courses (Brubaker, 2006; Fried, 2008; Gerow, Galluch \& Thatcher, 2010; Hembroke \& Gay, 2003; Kalayc1, 2010; Lauricella \& Kay, 2010; Li \& Chung, 2006; Yaşar \& Yurdugül, 2013). In other words, if students perform their personal tasks instead of the (internet-based) learning tasks they are responsible for, their learning interactions become absent, and/or their learning is incomplete, and this situation results in reduction of the course's effectiveness and efficiency. On the other hand, some researchers concluded that cyberloafing does not always lead to bad results. These studies reported that internet provides a flexible environment by reducing stress, therefore, it helps increase productivity in the job/task, contributes to creative thinking skills, improves social relationships, and leads to more active participation in learning environments by making access to information easier (Anandarajan \& Simmers, 2005; Belanger \& Slyke, 2002; Blanchard \& Henle, 2008; Kose et al., 2012; Lavoie \& Pychyl, 2001; Oravec, 2002; Polzer-Debruyne, 2008; Schraw, 2007; Seymour \& Nadesan, 2007; Stanton 2002; Ugrin et al., 2008; Vitak et al., 2011).

In a study that was conducted without focus on the positive and negative effects of technology on students, Ergün and Altun (2012) aimed to reveal the reasons for cyberloafing behaviors from the students' perspectives. As a result, they revealed five themes: motivation, the setting, instructor, attitudes towards the course, and time. The literature review by Kalayc1 (2010) investigated the factors that lead people to cyberloafing in two categories as individual variables and external variables. The study by Galluch and Thatcher (2007) in the scope of the Technology Acceptance Model found that interactions among students, structure of the classroom and course content were related to the cyberloafing behaviors of students.

Although many studies on the cyberloafing behaviors of employees in the workplace may be found in the literature, such studies are very limited in the field of education (Kalayc1, 2010). To this end, with the purpose of filling this gap in the field, it was aimed to investigate the learner-based and instructor-based reasons for students' cyberloafing behaviors and how these behaviors may be minimized to increase focus on the course from the perspective of students. 


\section{Method}

\section{Research Design}

This study, which aimed to investigate the reasons for prospective teachers' cyberloafing behaviors that are related to the learner and the instructor, used the qualitative design of case study. Qualitative case studies allow in-depth investigation of a case in question by a set of variables using a comprehensive approach (Şimşek \& Yıldırım, 2011).

\section{Participants}

The participants were determined by the method of random sampling for the sake of speed and practicality (Şimşek \& Yıldırım, 2011). The data were collected from 228 students who were registered in the Elementary School Teaching Program at the Faculty of Education of a state university located in the east of Turkey in the fall semester of the academic year of 2015-2016. While all students in the sample had smartphones, $78 \%$ used these to connect to the internet and $48 \%$ of the participants had notebook computers. The demographic information about the participants is given in Table 1 .

\section{Table 1}

Descriptive Statistics on the Gender and Class Level of the Participants

\begin{tabular}{lcccccc}
\hline & \multicolumn{2}{c}{ Female } & \multicolumn{3}{c}{ Male } & \multicolumn{2}{c}{ Total } \\
\cline { 2 - 7 } & $\mathrm{f}$ & $\%$ & $\mathrm{f}$ & $\%$ & $\mathrm{f}$ & $\%$ \\
\hline 1st year & 48 & 77.4 & 14 & 22.6 & 62 & 27.2 \\
2nd year & 43 & 72.9 & 16 & 27.1 & 59 & 25.9 \\
3rd year & 31 & 58.5 & 22 & 41.5 & 53 & 23.2 \\
4th year & 34 & 63.0 & 20 & 37.0 & 54 & 23.7 \\
Total & 156 & 68.4 & 72 & 31.6 & 228 & 100 \\
\hline
\end{tabular}

\section{Data Collection}

The participants were asked four open-ended questions which were prepared based on the studies conducted by Ergün and Altun (2012) and Galluch and Thatcher (2007). With these questions, the students were asked to state their learner-related and instructor-related reasons for focusing on extracurricular activities through various technologies. Additionally, they were 
asked about recommendations for instructors and the students themselves for minimizing such behaviors. Firstly, at the stage of preparing these questions, the language validity and content validity of the questions were checked by receiving expert opinion (one faculty member from the department of Turkish Instruction and two faculty members from the department of Computer Education and Instructional Technologies). For the purpose of checking content validity, the questions were directed to five students of another department in the same faculty, and it was confirmed that the questions were clear and comprehensible in terms of content.

The researchers visited each classroom at different times to collect the data and distributed the forms that contained the questions to the students. The participants were informed that participation in the study was voluntary, their names were not required, the data would be used only for the purposes of this study, and their information would never be shared with the third parties. It took around 25-30 minutes for participants to fill out the forms.

\section{Data Analysis}

The data were transferred to the electronic environment. While transferring the data, a specialized coding scheme was used to determine the order and class level of each participant (P3_38 - 3rd year, Participant 38). The data obtained were analyzed using the qualitative research method of content analysis. Qualitative data analysis consists of three basic stages as organization, summarization and interpretation (Büyüköztürk et al., 2008). The main process in content analysis is to gather similar data under certain concepts and themes; and then interpret them by organization (Şimşek \& Yıldırım, 2011). All the data obtained from the responses of the participants were analyzed under four main themes and additional sub-themes and codes: learner-based reasons, recommendations for students, instructor-based reasons, and recommendations for instructors. For reliability of the study, coding was made independently by two researchers. An overall inter-rater reliability of $92 \%$ was obtained for the categories. For the disagreements, the agreed consensus was used. 


\section{Findings}

\section{Findings about Instructors}

The data on instructor-related cyberloafing reasons are presented in Table 2. Six sub-themes were determined. These were; pedagogy-related issues, personal traits, issues related to classroom management, limited field knowledge and lack of breaks. The most frequently stated issues among the themes were issues related to pedagogic efficacy.

Table 2

Instructor-Related Cyberloafing Reasons

\begin{tabular}{|c|c|c|c|c|}
\hline & \multicolumn{4}{|c|}{ Class } \\
\hline & 1st year & 2nd year & 3rd year & 4th year \\
\hline Issues related to pedagogic efficacy & 33 & 30 & 28 & 24 \\
\hline $\begin{array}{l}\text { Teaching the course in a monotonous, boring and } \\
\text { uniform way }\end{array}$ & 23 & 29 & 24 & 24 \\
\hline $\begin{array}{l}\text { Not using different teaching methods and } \\
\text { techniques }\end{array}$ & 6 & 3 & 3 & 5 \\
\hline Not leading students to be active & 6 & 2 & 2 & 2 \\
\hline Coming to class unprepared & 2 & 2 & 4 & - \\
\hline Personal traits & 6 & 14 & 5 & 8 \\
\hline Issues related to communication skills & 10 & 6 & 1 & 9 \\
\hline Not using suitable tone of voice & 10 & 6 & 1 & 9 \\
\hline Classroom management & 6 & 3 & 8 & 9 \\
\hline Failure to achieve command of classroom & 3 & 1 & 8 & 2 \\
\hline Not walking around in classroom & 1 & 2 & 1 & 6 \\
\hline Focusing on same group of students & 2 & - & - & 1 \\
\hline Limited field knowledge & - & 1 & 6 & 5 \\
\hline Lack of breaks & 4 & 3 & 3 & 2 \\
\hline
\end{tabular}

The participants stated that they get very bored of the class and turn to different things when the instructor teaches the class monotonously. The responses of first and third year students P1_8 and P4_43 about the instructor's teaching of the class monotonously and uniformly are given below:

"I can get very sleepy when instructors talk about the subject for hours and process the class in a monotonous way." [P1_8]

"They teach the class monotonously because they consider the traditional approach on the attention of the classroom."[P4_43]

Fourth year student P4_36 had a similar response: 
"They teach the class in a monotonous way." [P4_36]

The participants stated that they get bored by an instructor teaching the class in a boring way and they started to dislike the course. The responses of the first and second year students P1_7 and P2_10 about the instructor's teaching of the class in a boring way were as seen below:

"The course instructor's boring way of teaching affects the student's prejudice about the course and [the student] starts to dislike the course." [P1_7]

"If a teacher is boring while teaching, the student deals with other things because they don't enjoy that class." [P2_10]

The participants stated that the class is very boring when the instructor does not make it interesting. Second year student P2_35 said:

"Instructor of the course not making it sufficiently interesting, ordinary way of instruction." [P2_35]

The participants stated that they get distracted from the class and they did not want to listen to it in times the instructor does not use different teaching methods and techniques. First year students P1_3 and P1_6 stated the following:

"They do not teach the subject by using different methods such as video, audio, images or supplementary instruments." [P1_3]

"If they do not teach in an exited manner and do not use different techniques, the student may be distracted and does not want to listen to the lecture." [P1_6]

P4_18 had a similar response:

"When they do not use different methods and techniques..." [P4_18]

The participants stated that they get bored and turn to different things as the instructor does not involve them in the class. The responses by first and fourth year students P1_27 and P4_13 were as the following:

"They cannot get students to focus and make them active [ly involved], this is why students are interested in mobile devices." [P1_27]

"If they are too harsh and forcing you to be disciplined and not allowing anyone to speak or participate in the class, the student may get bored and pay attention to 
something else." [P4_13]

The participants stated that class flow is very disorganized and boring when the instructor comes to the classroom unprepared. Third year student P3_17 stated the following:

"The instructor coming to the class unprepared." [P3_17]

The participants stated that the personal traits of the instructor also affected the class. First, third and fourth year students P1_54, P3_9, P4_11 stated the noteworthy insights below:

"High ego and belittling students." [P1_54]

“Lack of elocution skills.” [P3_9]

“Abnormal outfits, hairstyle, having an accent." [P4_11]

The participants stated that when the instructor does not use a suitable tone of voice, it creates distraction and as they speak in the class with the same tone of voice, students get sleepy. First and second year students P1_4 and P2_5 stated the following:

"Causing the student to get distracted or feel sleepy by teaching the class with constantly the same tone of voice." [P1_4]

"Not getting attention of students by sudden bursts, meaning sudden increases in their voice at a moment of calmness.” [P2_5]

Fourth year student P4_16 had a similar response:

“Tone of voice staying the same." [P4_16]

Regarding classroom management, the participants stated that the instructor cannot achieve discipline in the classroom, they do not walk around in the room and instructors always focus on the same students. First year student P1_27 stated the following:

"The instructor not being able to become dominant in the classroom. Because when the instructor is dominant, students also focus on the class and there is no problem as they do not turn to different things." [P1_27]

Likewise, the participants stated that when the instructor does not walk around and stays in the same place, this creates a comfortable setting for them, and they turn to doing other things. Third and fourth year students P3_9 and P4_12 stated that: 
"As they teach the class in front of the desk only, this creates a comfortable environment for us to use mobile devices." [P3_9]

"The instructor sitting in their place, teaching from a fixed position without walking around. No eye contact with students leads us to other things." [P4_12]

The participants stated that instructors have limited knowledge about the content. First year student P1_53 stated that:

“They do not have sufficient knowledge." [P1_53]

The participants stated that lack of breaks leads to distraction and gets students' attention away from the class. First year student P1_41's statement was noteworthy:

"The instructor might be too boring, like block classes. This can distract the student and so the student resorts to activities unrelated to the class." [P1_41]

Likewise, fourth year student P4_17:

"They do not give any breaks.” [P4_17]

Table 3 shows the possible solutions that would prevent cyberloafing activities that are instructor-related. In general, lack of pedagogic skills that the participants especially complained about became prominent here as well, and the participants stated that instructors should improve themselves regarding this issue.

Table 3

Solutions for Instructor-Based Reasons for Cyberloafing

\begin{tabular}{lcccc}
\hline & \multicolumn{3}{c}{ Class } \\
\cline { 2 - 5 } & 1st year & 2nd year & 3rd year & 4th year \\
\hline Pedagogic skills & 40 & 40 & 40 & 43 \\
Interesting and fun teaching & 29 & 23 & 11 & 21 \\
Using different methods and techniques & 9 & 15 & 25 & 24 \\
Making students actively involved & 11 & 8 & 14 & 14 \\
Coming prepared & 2 & 3 & 5 & 1 \\
Classroom management & 5 & 6 & 9 & 8 \\
Achieving discipline in the class & 4 & 4 & 8 & 4 \\
Walking around in the classroom & 1 & 2 & 1 & 5 \\
Personal traits & 8 & 8 & 5 & 6 \\
Communication & 7 & 2 & 1 & 9 \\
Using tone of voice well & 7 & 2 & 1 & 9 \\
Giving breaks & 6 & 5 & 1 & - \\
Enriching field knowledge & 3 & 1 & 4 & 3 \\
\hline
\end{tabular}




\section{Findings about the Student}

The data on learner-related cyberloafing reasons are presented in Table 4. Eight sub-themes were determined. These were; personal problems, disinterest in the course, disliking the course, distractibility, coming to the classroom unprepared, lack of motivation, disliking the instructor, not getting used to the setting. The most frequently emphasized sub-theme was the personal problems of the student.

Table 4

Learner-Related Cyberloafing Reasons

\begin{tabular}{lcccc}
\hline & \multicolumn{3}{c}{ Class } \\
\cline { 2 - 5 } & 1st year & 2nd year & 3rd year & 4th year \\
\hline Personal problems & 17 & 27 & 18 & 15 \\
$\quad$ Personal issues & 8 & 15 & 12 & 6 \\
Lack of sleep & 8 & 7 & 1 & 7 \\
Illness & 1 & 6 & 4 & 3 \\
$\quad$ Fatigue & - & 1 & - & 4 \\
Disregard, indifference for the course & 10 & 15 & 7 & 9 \\
Disliking the course & 13 & 6 & 9 & 5 \\
Distractibility & 7 & 11 & 8 & 4 \\
Coming to the classroom unprepared & 9 & 5 & 5 & 2 \\
Lack of motivation & 4 & 1 & 4 & 9 \\
Disliking the instructor & 3 & 1 & 3 & 4 \\
Not getting used to the setting & 7 & 1 & - & - \\
\hline
\end{tabular}

Personal issues were the most frequently stated problems among personal problems. The participants stated in general that psychological, family, financial-spiritual problems led to distraction from the class. First and third year students P1_2, P1_15 and P3_3 stated about personal issues that:

"There is incompatibility between the subject I am studying and I." [P1_2]

"[A student] may dislike the subject or have come to that city or university because of the pressure from others." [P1_15]

"There may be problems that the student cannot get out of their head, other issues in their mind." [P3_3]

The participants said lack of sleep may prevent listening to the class. First year student P1_9 said:

"I am in sleep mode in the classroom." [P1_9] 
The participants stated that, in the case of their lack of interest in the class, the disturbance created by peers who disregard the class may also lead others to get distracted from the class. The first, second, third and fourth year students P1_42 and P2_22 stated the following:

"If the classroom is uninterested in the class, everyone gets distracted, fails to concentrate and tries different options." [P1_42]

"As the interest in, desire for and positive attitude towards the class are low, both the course and the instructor move away from us." [P2_22]

The participants stated that their peers who do not like the course turn towards different activities. First year students P1_7 and P1_31 stated the following:

"If the students do not like that course, they will be prejudiced against it, and if they do not do what is needed, their minds go elsewhere, and this separates the student from the course entirely." [P1_7]

"If the student says they do not like and cannot manage this course, of course, they will not listen. If not listening to the class, they would deal with mobile devices." [P1_31]

Similarly, second year student P2_6 said:

"I dislike the course." [P2_6]

The participants stated that they could not focus on the class because of distractibility, and therefore, resorted to cyberloafing via mobile devices and the internet. Third year student P3_7 said:

"I cannot focus on the class because of distractibility and I turn to different things." [P3_7]

The participants stated that they turn to different things in the case that they arrived at the classroom unprepared. First year student P1_44:

"I use my mobile device when I come to the class unprepared." [P1_44]

The participants stated that they get distracted from the class and start dealing with other things in cases of lack of motivation. First and fourth year students P1_3 and P4_51 had noteworthy 
statements:

"After a point, at most 30 minutes, my concentration is disrupted, and I turn to different activities." [P1_3]

"Lack of motivation leads the student to deal with other things." [P4_51]

The participants stated that they did not like the course if they did not like the instructor, this way they did not care for the class and they did not participate in it.

Similarly, they stated that they turn towards mobile devices as they cannot get used to the class setting. First year student P1_23 stated the following:

"I always feel the need for mobile devices and use them as I have not completely gotten used to the class and the city and sometimes I need to get rid of my loneliness." [P1_23]

Table 5 shows the possible solutions for preventing learner-related cyberloafing activities. The participants, in general, stated that they have no opportunities to turn to other activities when they are interested in the class and they are listening to the class.

Table 5

Solutions for Learner-Related Reasons for Cyberloafing

\begin{tabular}{lcccc}
\hline & \multicolumn{3}{c}{ Class } \\
\cline { 2 - 5 } & 1st year & 2nd year & 3rd year & 4th year \\
\hline Listening to, being interested in the & 15 & 17 & 8 & 9 \\
class & 16 & 14 & 4 & 6 \\
Coming to class prepared & 6 & 3 & 10 & 2 \\
Turning phones off & 6 & - & 2 & 2 \\
Keeping away from social media & 4 & 1 & - & 5 \\
Achieving motivation & 7 & - & 1 & 1 \\
Liking the course & 3 & 4 & - & 2 \\
Getting enough sleep & 2 & 1 & 1 & 1 \\
Concentrating & 3 & 1 & 1 & - \\
Adapting to the setting & 3 & - & - & - \\
Being in agreement with friends & & & & \\
\hline
\end{tabular}




\section{Results, Discussion and Recommendations}

The opinions of the prospective teachers on the learner-related and instructor-related reasons for cyberloafing are discussed here.

\section{Instructors}

The definition of effective teaching has been investigated in all disciplines and by several researchers in detail (see Bransford, Brown \& Cocking, 1999; Jang, 2008; Pintrich \& Schunk, 1996). It is known that the lead role in training qualified individuals is the teachers in the education process (Büyükkaragöz \& Çivi, 1999). For effective education teachers should improve themselves scientifically and academically, but this is not enough (Açıkgöz, 2003). This is because however much knowledge teachers might have about the subjects they will teach, they cannot be successful in their profession as long as they cannot transfer it to their students (Erden, 1999).

Several studies (Cerrah, Özsevgeç, \& Ayas, 2005; Matyar, Denizoğlu, \& Özcan, 2008; Nazlıçiçek \& Akarsu, 2008; Uşak, 2005) concluded that teachers and prospective teachers in different fields have insufficient knowledge required by their profession. Studies conducted at different periods revealed that teachers mainly use one method and they are inadequate in enriching the education process by combining different methods. Emiroğlu (2002) reported that teachers cannot go further than traditional options in selecting and using teaching methods.

The participants in this study stated that instructors taught the course monotonously and boringly, and did not use different teaching methods and techniques. They stated that, because of this, they did not listen to the instructor, but they turned towards different areas (mobile phones, notebook computers and internet) and carried out cyberloafing behaviors. Therefore, it is important to train instructors to be employed in the education system before and during their service properly, not only in terms of the quality of education services (Şişman, 2011) but also because it prevents students from cyberloafing behaviors as they cannot turn towards different things. 
Studies reported that teachers are inadequate in body language usage among communication skills (Çalışkan, 2003; Yeşil, 2006). This study also observed parallel results. The participants stated regarding the personal traits of the instructor that they had complaints about; issues related to communication skills, failure to use tone of voice, issues related to class management including not walking around in the classroom and being able to dominate the class. They stated that, because of this, they did not listen to the instructor, but took part in cyberloafing behaviors.

Achieving effective teaching in our schools is dependent on presence of qualified teachers (Seferoğlu, 2004). For effective teaching, teachers' knowledge of the field, pedagogical knowledge, personal traits and class management skills are seen to have a key role. In this context, future studies aiming effective teaching and qualified education should focus on issues of pedagogical knowledge and communication skills of teachers, and issues related to classroom management.

\section{Students}

According to the literature, personal issues, disregard for the course, not listening to the instructor and coming to the classroom unprepared are among the most frequently encountered undesired behaviors (Atici, 1999; 2004; Bulucu, 2003; Ding, Li, Li, \& Kulm, 2008; Greenlee \& Ogletree, 1993; Little, 2005). This study also observed parallel results. Some undesired behaviors are observed due to personal problems and these lead students to turn towards different activities and show cyberloafing behaviors. Studies reported that reasons for such behaviors include health problems of students (Schweitzer, 1996) and family issues (Bilgin, 2000). This study found that the participants were concerned the most with personal problems and among these personal problems, especially health issues and family problems.

Defining variables in future studies and working with different samples may provide important contributions to the literature. Additionally, future studies may focus on the concept of motivation. The relationship between variables that affect motivation and cyberloafing behaviors may be investigated by focusing on the motivation of the instructor and/or the student. For example, the ARCS model developed by Keller and the Hierarchy of Needs by Maslow may be accepted as the theoretical framework and the basic elements that form these models may be analyzed as variables. 
The findings obtained from this study include recommendations for teachers. First of all, considering that today's students use technology intensively, teachers should also have sufficient knowledge about technology. By integrating technology in their classes with this knowledge, for example, they may show their students how the internet can be used for educational purposes. The second recommendation is that teachers organize their way of teaching the class to actively involve students. They may use various games, videos and different teaching methods to keep students' motivation high, and therefore, support their learning. This way, tendency of students to turn towards unrelated activities during classes may be reduced.

Consequently, it was seen with this study that there was agreement between the variables in the literature that have already been discussed and that define qualified teachers and the complaints by the prospective teachers that were outlined here. Considering that usage of smartphones, notebook computers, wireless networks and other mobile technologies is increasingly becoming prevalent and the structure of a learner (for example, their internal and external motivation) is constantly changing in connection to this, it is expected that the findings of this study will light the way for future studies. 


\section{References}

Açıkgöz, K. (2003). Etkili öğrenme ve öğretme. İzmir: Eğitim Dünyası Yayınları.

Anandarajan, M., Devine, P., \& Simmers, C. (2004). A multidimensional scaling approach topersonal web usage in the workplace. In M. Anandarajan ve C. Simmers (Eds.), Personal web usage in the workplace: A guide to effective human resource management. Hershey, PA: Information Science Publishing.

Atıc1, M. (1999). Illkokul ögrretmenlerinin sınıf yönetiminde yetkinlik beklentisi rolünün Ingiltere ve Türkiye'de seçilen bir araştırma grubu üzerinde incelenmesi. Yayınlanmamış Doktora Tezi. Leicester Üniversitesi. İngiltere.

Atıc1, M. (2004). İlköğretim öğrencilerinin davranış problemleriyle baş etme konusunda öğretmen psikolojik danışman işbirliğine ilişkin görüşlerin karşılaştırılması. Türk Psikolojik Danışma ve Rehberlik Dergisi, 3(25), 55- 65.

Barak, M., Lipson, A., \& Lerman, S. (2006). Wireless laptops as means for promoting active learning in large lecture halls. Journal of Research on Technology in Education, 38(3), 245-263.

Belanger, F. \& Van Slyke, C. (2002). Abuse or learning? Communications of the ACM, 45(1), 64-65

Bilgin, M. (2000). Üniversite Öğrencilerinin Sorunları ile Değerleri Arasındaki İlişkilerin İncelenmesi. Çukurova Üniversitesi Ĕ̌itim Fakültesi Dergisi, 2, 18-25.

Blanchard, A.L., \& Henle, C.A. (2008). Correlates of different forms of cyberloafing: The role of norms and external locus of control. Computers in Human Behavior, 24, 1067-1084.

Bock, G,-W., \& Ho, S.L.(2009). Non-work related computing (NWRC). Communications of the ACM, 52(4), 124-128.

Bransford, J.D., Brown, A.L., \& Cocking, R.R. (1999). How people learn: Brain, mind, experience, and school. National Academy Press.

Brubaker, A.T. (2006). Faculty perceptions of the impact of student laptop use in a wireless internet environment on the classroom learning environment and teaching information and library science. The Faculty of the School of Information and Library Science of the University of North Carolina, Master Dissertation.

Bulucu, Ö. (2003). İlköğretim I. kademe öğretmenlerinin sınıf davranış yönetiminde yetkinlik algılarının bazı değişkenler açısından incelenmesi. Yayımlanmamış yüksek lisans tezi, Çukurova Üniversitesi Sosyal Bilimler Enstitüsü, Adana. 
Büyükkaragöz, S., \& Çivi, C. (1999). Genel ögrretim metodları ögretimde planlama uygulama (10. Bask1). İstanbul: Beta Basım Yayım AŞ.

Cerrah, L., Özsevgeç, T., \& Ayas, A. (2005). Biyoloji öğretmen adaylarının lise II öğretim programı konusundaki bilgi düzeyleri: Trabzon örneklemi. İnönü Üniversitesi Eğitim Fakültesi Dergisi, 6(9), 15-25.

Çalışkan, N. (2003). Sınıf öğretmenlerinin sözel olmayan iletişim davranışlarının değerlendirilmesi. Yayımlanmamış Doktora Tezi. Atatürk Üniversitesi, Erzurum, 1003.

Demb, A., Erickson, D., \& Hawkins-Wilding, S. (2004). The laptop alternative: Student reactions and strategic implications. Computers \& Education, 43(4), 383-401.

Ding, M., Li, Y., Li, X., \& Kulm, G. (2008). Chinese teachers' perceptions of students' classroom misbehaviour. Educational Psychology, 28(3), 305-324.

Emiroğlu, G. (2002). İlköğretim TC İ. TA ders konularının öğretiminde kullanılan metot, etkinlik ve öğrenci aktivitelerine yönelik öğretmen görüşleri üzerine bir araştırma. Ata Dergisi, 10, 45-64.

Erden, M. (1999). Öğretmenlik mesleğine giriş, Ankara: Alkım Yayınları.

Ergün, E., \& Altun, A. (2012). Öğrenci gözüyle siber aylaklık ve nedenleri. Eğitim Teknolojisi: Kuram ve Uygulama, 2(1), 36-53.

Finn, S., \& Inman, J.G. (2004). Digital unity and digital divide: Surveying alumni to study effects of a campus laptop initiative. Journal of Research on Technology in Education, 36(3), 297-317.

Fitch, J.L. (2004). Student feedback in the college classroom: a technology solution. Educational Technology Research and Development, 52, 171-181.

Fried, C. (2008). In-class laptop use and its effects on student learning. Computers \& Education, 50(3), 906-914.

Gerow, J.E., Galluch, P.S., \& Thatcher, J.B. ,(2010). To slack or not to slack: internet usage in the classroom. Journal of Information Technology Theory and Application, 11(3), 5-24.

Greenlee, A.R., \& Ogletree, E.J. (1993). Teachers' attitudes toward student discipline problems and classroom management strategies, USA. Illinois, 18, ED36430.

Hembrooke, H., \& Gay G.(2003) The laptop and the lecture: The effects of multitaskingin learning environments. Journal of Computing in Higher Education, 15(3), 46-64.

Hyden, P. (2005). Teaching statistics by taking advantage of the laptop's ubiquity. New Directions for Teaching and Learning, 101, 37-42.

Jang, H. (2008). Supporting students' motivation, engagement, and learning during an uninteresting activity. Journal of Educational Psychology, 100(4), 798-811. 
Jones, S. (Ed.). (2002). Encyclopedia of new media: An essential reference to communication and technology. Sage Publications.

Kalayc1, E. (2010). Üniversite öğrencilerinin siber aylaklık davranışları ile özdüzenlemeStratejileri arasındaki ilişkinin incelenmesi. Yayınlanmamış Doktora Tezi. Hacettepe Üniversitesi/Fen Bilimleri Enstitüsü,Ankara, Turkey.

Köse, S., Oral, L., \& Türesin,H. (2012). İş yaşamında sosyal kolaylaştırma kavramı vesanal kaytarma ile ilişkisi: araştırma görevlileri üzerinde bir araştırma. Sosyal ve Beşeri Bilimler Dergisi, 4(1), 287-295.

Lauricella, S., \& Kay, R. (2010). Assessing laptop use in higher education classrooms: The laptop effectiveness scale (LES). Australasian Journal of Educational Technology, 26(2).

Lavoie, J.A.A., \& Pychyl, T.A. (2001). Cyberslacking and the procrastinationsuperhighway: A Web- based survey of online procrastination, attitudes, and emotion. Social Science Computer Review, 19(4), 431-444.

Li, S.M., \& Chung, T.M. (2006). Internet function and Internet addictive behavior. Computers in Human Behavior, 22(6), 1067-1071.

Lim, V.K.G. (2002). The IT way of loafing on the job: Cyberloafing, neutralizing andorganizational justice. Journal of Organizational Behavior, 23(5), 675-694.

Little, E. (2005). Secondary school teachers' perceptions of students' problem behaviours, Educational Psychology, 25(4), 369-377, DOI: 10.1080/01443410500041516.

Matyar, F., Denizoğlu, A.G.P., \& Özcan, M. (2008). Sınıf Öğretmenliği Abd'de Okuyan 4 sınıf Öğrencilerinin ilköğretim Birinci Kademe Fen Ve Teknoloji Dersine ilişkin Alan Bilgilerinin Belirlenmesi çukurova Üniversitesi Örneği. Çukurova Üniversitesi Sosyal Bilimler Enstitüsü Dergisi, 17(1).

Mitra, A., \& Steffensmeier, T. (2000). Changes in student attitudes and student computer use in a computer- enriched environment. Journal of Research on Computing in Education, 32(3), 417-433.

Nazlıçiçek, N., \& Akarsu, F. (2008). Fizik, kimya ve matematik öğretmenlerinin değerlendirme araçlarıyla ilgili yaklaşımları ve uygulamaları. Eğitim ve Bilim, 33(149), 18-29

Oravec, J.A. (2002). Constructive Approaches to Internet Recreation in the Workplace, Communications of the ACM, 45(1):60-63.

Phillips, J.G., \& Reddie, L. (2007). Decisional style and self-reported Email use in the workplace. Computers in Human Behavior, 23(5), 2414-2428. 
Pintrich, P.R., \& Schunk, D. (1996) The Role of Expectancy and Self-Efficacy Beliefs: Motivation in Education. Theory, Research and Application. Englewood Cliffs, NJ: Prentice-Hall.

Polzer-Debruyne, A.M. (2008). Psychological and workplace attributes that influence personal web Use $(P W U)$. Yayınlanmamış Doktora Tezi, Endüstiryel/Örgütsel Psikoloji, Massey Üniversitesi, New Zealand.

Schraw, G., Olafson, L., Kuch, F., Lehman, T., Lehman, S., \& McCrudden, M.T. (2007). Interest and academic cheating. Psychology of academic cheating, 59-85.

Seferoğlu, S.S. (2004). Öğretmen yeterlilikleri ve mesleki gelişim. Eğitim Dergisi, 58, 40-41.

Seymour, L., \& Nadasen, K. (2007). Web access for IT staff: a developing world perspective on web abuse. The Electronic Library, 25(5), 543-557.

Şişman, M. (2011). Eğitim bilimine giriş. Pegem Akademi.

Stanton, J.M. (2002). Company profile of the frequent internet user. Communications of the ACM, 45(1), 55-59.

Steffens, K. (2001). Self-regulation and computer-based learning. Anuario de psicología, 32, 77-94.

Stephens, B.R. (2005). Laptops in psychology: conducting Xexible in-class research andwriting laboratories. New Directions for Teaching and Learning, 101, 15-26.

Şimşek, H., \& Yıldırım, A. (2011). Sosyal bilimlerde nitel araştırma yöntemleri. Ankara: Seçkin Yayıncılık.

Ugrin, J., Odom, M., \& Pearson, J. (2008). Exploring the importance of mentoring for newscholars: A social exchange perspective. Journal of Information Systems Education19(3), 343-350.

Uşak, M. (2005). Fen bilgisi ögretmen adaylarının çiçekli bitkiler konusundaki pedagojik alan bilgileri. Yayımlanmamış Doktora Tezi. Gazi Üniversitesi Eğitim Bilimleri Enstitüsü. Ankara.

Vitak, J., Crouse, J., \& LaRose, R. (2011). Personal Internet use at work: Understanding cyberslacking. Computers in Human Behavior, 27, 1751-1759.

Weaver, B.E., \& Nilson, L.B. (2005). Laptops in class: What are they good for? What can you do with them? New Directions in Teaching and Learning, 101, 3-13

Whitty, M.T., \& Carr, A.N. (2006). New rules in the workplace: Applying object-relations theory to explain problem Internet and email behavior in the workplace. Computers in Human Behavior, 22(2), 235-250. 
Yaşar, S., \& Yurdugül, H. (2013). The Investigation of Relation Between Cyberloafing Activities and Cyberloafing Behaviors in Higher Education. Procedia-Social and Behavioral Sciences, 83, 600-604.

Yeşil, R. (2006). Sosyal bilgiler öğretmenlerinin sınıf içi öğretim yeterlikleri (Kırşehir Örneği). Ahi Evran Üniversitesi Kırşehir Ĕ̈itim Fakültesi Dergisi, 7(2). 